\title{
SHORELINE EVOLUTION NEAR THE MOUTH OF THE PETRACE RIVER, REGGIO CALABRIA, ITALY
}

\author{
MANUELA MARIA BORRELLO, GIANDOMENICO FOTI \& PIERFABRIZIO PUNTORIERI \\ Mediterranea University of Reggio Calabria, DICEAM Department, Italy
}

\begin{abstract}
The paper shows the shoreline evolution near the mouth of the Petrace River, which is located in the southern part of Calabria (Italy) and is the largest in the province of Reggio Calabria besides the Mesima River, whose watershed, however, mostly belongs to the province of Vibo Valentia. From a morphometric point of view, it has an area of over $420 \mathrm{~km}^{2}$, has a maximum height of $1900 \mathrm{~m}$ (originating in the massive of Aspromonte) and has an average height of about $550 \mathrm{~m}$. From a hydrographic point of view, it has a main stream length of more than $40 \mathrm{~km}$, has Horton's order of 7 , and is characterized by a torrential regime with an annual average flow rate of about $8 \mathrm{~m}^{3} / \mathrm{h}$. The river mouth is situated in the Tyrrhenian Sea between the municipalities of Palmi and Gioia Tauro. The shoreline evolution over the last 60 years has been studied using the QGIS software and analyzing the free cartography data of the National Cartographic Portal, the cartographies provided by the Calabria Basin Authority and satellite imagery provided by Google Earth. At the mouth of the Petrace River, both positive (in the last 10 years, in the order of tens of meters) and negative (between the 1950s and 1980s, in the order of hundreds of meters) variations of the shoreline have been observed. The paper also analyzes the main factors influencing the coastal dynamics, in particular the longshore and river transport, the deep-water wave climate, the rainfall regime, the variations in soil use and the presence of hydraulic structures.

Keywords: shoreline evolution, longshore sediment transport, river sediment transport, deep water wave climate, rainfall regime, soil use, hydraulic structures.
\end{abstract}

\section{INTRODUCTION}

Coastal area represents the transition zone between sea and land and is of particular importance for the presence of housing settlements (over $30 \%$ of the world [1] and Mediterranean [2] lives a short distance away from the coastline) and economic activities, most of which are related to tourism [3].

Coastal dynamics are influenced by both natural and anthropic factors [4], both in the coastal strip and in river basins in the reference hydrogeological unit. Among the anthropogenic factors [5], the construction of buildings, infrastructures, ports and coastal defense works [6]-[10] are of particular importance, which in most cases involve the destruction of coastal dunes [11], the realization of hydraulic structures interfering with fluvial dynamics such as dams, bridges, inert drains from river basins, soil waterproofing linked to its anthropization, and the development of economic activities, in particular tourism. [12]. Among the natural factors influencing the temporal and spatial evolution of the shoreline [13], [14], the action of wave motion [15]-[21] and the interaction between longshore and river transport [22]-[28].

The demographic increases and the remarkable anthropism that characterized the second half of the last century have had a major impact on the equilibrium of the Italian and Calabrian coasts [29], [30], accentuated by the high coastal development of both territories (over 7500 $\mathrm{km}$ of coast for Italy and over $700 \mathrm{~km}$ for Calabria).

Misdiagnosis of the factors listed above can lead to environmental disasters as in the case of Saline Joniche in the province of Reggio Calabria [31] so for the proper management of 
the coast it is of fundamental importance to know all the factors influencing the coastal dynamics [32], [33].

The paper describes the characteristics of the area object of study, the shoreline evolution over the last 60 years near the mouth of the Petrace River and, also, analyzes the main factors influencing the coastal dynamics, in particular the longshore and river transport, the deepwater wave climate, the rainfall regime, and the presence of hydraulic structures.

\section{SITE DESCRIPTION}

The Petrace River is located in the southern part of Calabria (Italy) and is the largest in the province of Reggio Calabria besides the Mesima River, whose watershed however mostly belongs to the province of Vibo Valentia. From a morphometric point of view, it has an area of over $420 \mathrm{~km}^{2}$, has a maximum height of $1900 \mathrm{~m}$ (originating in the massive of Aspromonte) and has an average height of about $550 \mathrm{~m}$. From a hydrographic point of view, it has a main stream length of more than $40 \mathrm{~km}$, is articulated in several sub-basins, has Horton's order of 7 and is characterized by a torrential regime with an annual average flow rate of about $8 \mathrm{~m}^{3} / \mathrm{h}$. From the geological point of view, it is made up of sedimentary soils in the central and northern parts and metamorphic rocks in the southern part. The river mouth is situated in the Tyrrhenian Sea between the municipalities of Palmi and Gioia Tauro. The river influence area extends from the mouth of the Petrace River to the port of Palmi due to the predominant longshore sediment transport direction.

\section{HISTORICAL EVOLUTION OF THE SHORELINE}

The historical evolution of the shoreline is evaluated through the comparison of cartography data, provided by the Calabria Basin Authority, which consists of aero photogrammetry (by CASMEZ, 1954 and IGM, 1985), aerial photos ("orthophotos", of 1989, 1996, 1998, 2000, 2006, 2008 and 2012) taken from the Open Data section of the National Geoportal and satellite imagery (of 2003, 2005 and 2011) provided by Google Earth Pro.

From the analysis of the results shown in Table 1 it is possible to note that at the mouth of the Petrace River are alternated periods of advancement and erosion, often of considerable

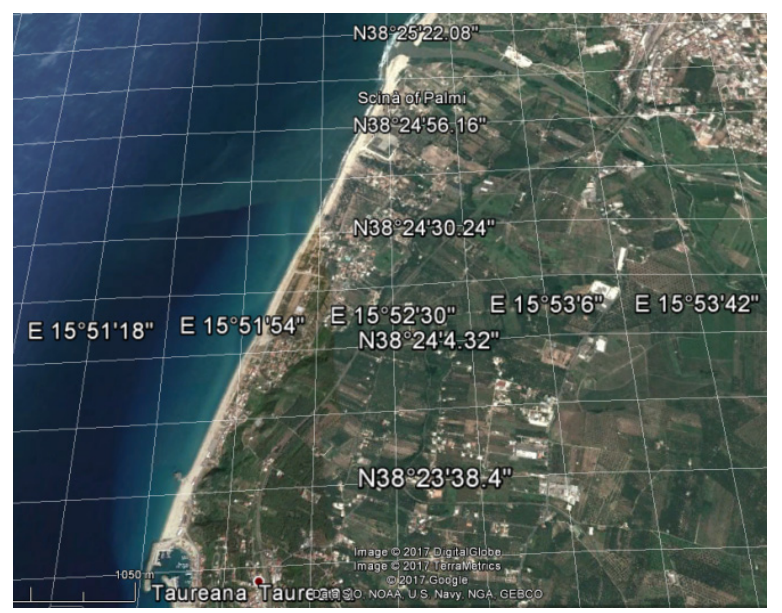

Figure 1: River influence area, between the mouth of the Petrace River (north) and the port of Palmi (south). 
magnitude. In particular, between 1954 and 1985 it is possible to observe the greatest erosion, with value of about $200 \mathrm{~m}$. The erosion process continued until 1989, although smaller, while between 1989 and 1998 the coastline underwent small variations so that it could be considered in equilibrium conditions. From 1998 to 2005, however, an advancement was observed, abruptly abolished in 2006 (between 2005 and 2006 there was an erosion of more than $40 \mathrm{~m}$ ). From 2006 to 2011, it is possible to observe a progress phase that has reached its peak between 2008 and 2011 has gone up by about 100 m, while between 2011 and 2012 there is a new erosive phase, with a retreat greater than $50 \mathrm{~m}$.

\section{WAVE CLIMATE}

The wave climate was analysed using the ABRC-MaCRO software, developed by HR Wallingford Ltd. This software allows us to obtain time series of wave data, starting from the information available at the Met Office database. This database is composed of data reconstructed via the European Wave Model starting from wind field data. The software is based on the HINDWAVE model [34], which is implemented starting with the following input data: the geometric characteristics of the area under investigation, and the wind field velocity in the area. The calculation is carried out in two stages: firstly, a table with all the combinations of wave data compatible with the characteristics of the site is defined, then wind records are analysed to identify which wave conditions are better correlated with current records. The model was calibrated via the buoy wave data recorded in Crotone (Ionian Sea) and Cetraro (Tirrenian Sea). This data was provided by the Rete Ondametrica Nazionale (RON).

The time series obtained from the software starts on $10^{\text {th }}$ January 1986 and finishes on $31^{\text {st }}$ March 2006 and it's composed by 170,929 recorded. Starting from the time series, the following were calculated: frequency of occurrence, significant wave height, peak period, mean energy flux, longshore sediment transport.

The maximum values of the various parameters are observed in the sector that forms an angle of $300^{\circ}$ from the north and adjacent sectors. In particular, the frequency of occurrence is about $12 \%$, the significant wave height is about $1 \mathrm{~m}$, the peak period is about $4 \mathrm{~s}$ and the mean energy flux is slightly above $1600 \mathrm{~N} / \mathrm{s}$. Finally, longshore sediment transport, estimated by the model of Tomasicchio et al. [25], is about $120000 \mathrm{~m}^{3} /$ year and is oriented from north to south.

Table 1: Shoreline evolution in the area under study. Legend: red = erosion; green $=$ advancement; negative $=$ erosion; positive $=$ advancement.

\begin{tabular}{|l|l|c|c|c|}
\hline Date & Typology & Beach amplitude [m] & Variation [m] & Variation [\%] \\
\hline 1954 & Aero photogrammetry & 265 & - & - \\
\hline 1985 & Aero photogrammetry & 74 & -191 & -72 \\
\hline 1989 & Aerial photos & 58 & -16 & -22 \\
\hline 1996 & Aerial photos & 57 & -1 & -2 \\
\hline 1998 & Aerial photos & 53 & -4 & -7 \\
\hline 2003 & Satellite imagery & 73 & 20 & 38 \\
\hline 2005 & Satellite imagery & 89 & 16 & 22 \\
\hline 2006 & Aerial photos & 50 & -39 & -44 \\
\hline 2008 & Aerial photos & 61 & 11 & 22 \\
\hline 2011 & Satellite imagery & 156 & 95 & 156 \\
\hline 2012 & Aerial photos & 100 & -56 & -36 \\
\hline
\end{tabular}




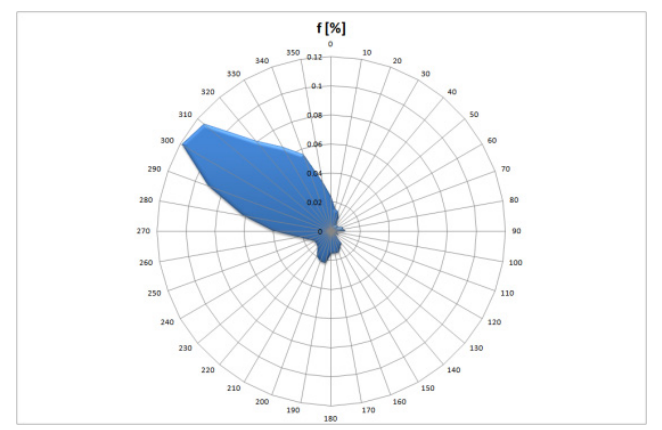

Figure 2: Frequency of occurrence, the maximum value is about $12 \%$.

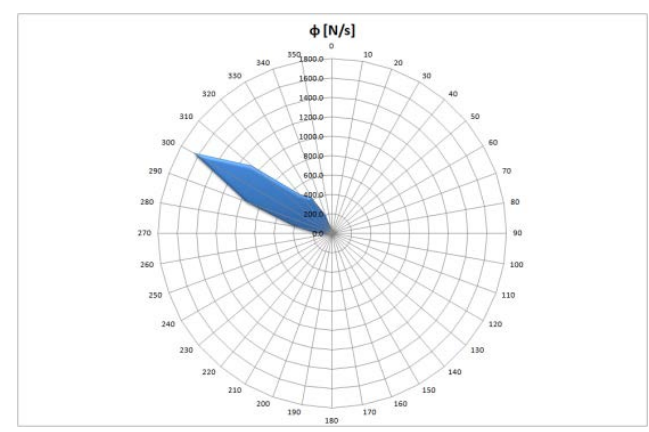

Figure 3: Mean energy flux, the maximum value is about $1600 \mathrm{~N} / \mathrm{s}$.

\section{RIVER SEDIMENT TRANSPORT}

To study the river sediment transport variations hydraulic structures, rainfall and temperature time series and river sediment contribution were analysed.

\subsection{Hydraulic structures}

The latest census of hydraulic structures in the Petrace River dates back to 1998 and 192 transverse works were surveyed, of which 19 destroyed, while longitudinal works extend for about $50 \mathrm{~km}$ and the percentage of the hydrographic grid affected by the structures is higher than $40 \%$. Most of the structures were carried out along 6 tributaries (Razzà, Serra, Marro, Crasta, Ferrandina, Boscaino) and only a small part along the main stream. In addition, approximately $20 \%$ of cross-sectional structures consist of isolated works realized in the first and second order of Horton and about $80 \%$ of the works (both longitudinal and transverse) are works of gravity in concrete.

From the point of view of the effects generated from the placement works it has been observed that $20 \%$ of the main stream has an elevation of the bottom.

\subsection{Rainfall and temperature time series}

There are 19 gauges in the river basin of the Petrace River and in its neighboring areas, but 9 of them show only rainfall data and not temperature data (as shown in Table 2). Table 3 
shows the elevation of each gauge and the average recorded rain and temperature values. Table 4 shows the average rainfall values of the only active gauges from a sufficiently large period before 1954 to date, divided into time intervals consistent with those identified in the paragraph on the shoreline evolution.

From the analysis of the results shown in Table 4 it can be observed that before the year 1954, when the maximum width of the beach at the mouth of the Petrace River was observed, the rains recorded by almost all the gauges (with the exception of Rizziconi gauge) are higher than the average value recorded over the entire period. Even in the period 2007-2011, where a remarkable advancement of the shoreline was observed, 4 of 8 gauges recorded higher values than the average of the whole period, 3 gauges recorded values slightly below this average and only the Cittanova gauge it has markedly lower values.

It should also be noted that between 1951 and 1953 almost all of the province of Reggio Calabria was affected by two intense alluvial events.

Table 2: Period of recording of each gauge.

\begin{tabular}{|c|c|c|c|c|}
\hline \multirow[t]{2}{*}{ Gauge } & \multicolumn{2}{|c|}{ Rainfall } & \multicolumn{2}{|c|}{ Temperature } \\
\hline & Period & $\begin{array}{c}\text { Number of } \\
\text { years available }\end{array}$ & Period & $\begin{array}{c}\text { Number of } \\
\text { years } \\
\text { available }\end{array}$ \\
\hline $\begin{array}{c}\text { Antonimina Canolo } \\
\text { Nuovo }\end{array}$ & 1951-2017 & 55 & 1963-2017 & 53 \\
\hline Bagnara Calabra & $1922-2017$ & 73 & $2002-2006$ & 5 \\
\hline Cittanova & 1916-2017 & 93 & 1924-2017 & 85 \\
\hline $\begin{array}{c}\text { Gambarie } \\
\text { d'Aspromonte }\end{array}$ & $1929-2017$ & 78 & 1939-2017 & 66 \\
\hline Gioia Tauro & $1922-1987$ & 55 & n.a. & n.a. \\
\hline Gioia Tauro Budello & 2011-2017 & 7 & n.a. & n.a. \\
\hline Molochio & 1952-2017 & 63 & n.a. & n.a. \\
\hline Oppido & $1916-1950$ & 34 & n.a. & n.a. \\
\hline Oppido Castellace & 1940-2004 & 63 & $2002-2006$ & 5 \\
\hline Palmi & 1916-2017 & 75 & 1924-1979 & 51 \\
\hline Perrone & $1940-1962$ & 16 & n.a. & n.a. \\
\hline Platì & 1920-2017 & 96 & 1992-2017 & 25 \\
\hline Rizziconi & $1922-2017$ & 93 & $2005-2017$ & 13 \\
\hline $\begin{array}{l}\text { Rizziconi Ponte } \\
\text { Vecchio }\end{array}$ & 1940-2017 & 26 & n.a. & n.a. \\
\hline San Luca Polsi & 1928-2005 & 59 & 1992-2005 & 14 \\
\hline Santa Cristina & $1937-2017$ & 80 & 1988-2017 & 30 \\
\hline Scifà & 1954-1965 & 12 & n.a. & n.a. \\
\hline Sinopoli & 1916-2017 & 100 & n.a. & n.a. \\
\hline Taurianova & $2011-2017$ & 7 & n.a. & n.a. \\
\hline
\end{tabular}


Table 3: Average annual rainfall and temperature for each gauge.

\begin{tabular}{|l|l|l|l|}
\hline Gauge & $\begin{array}{l}\text { Elevation } \\
{[\mathrm{m}]}\end{array}$ & $\begin{array}{l}\text { Average rainfall } \\
{[\mathrm{mm}]}\end{array}$ & $\begin{array}{l}\text { Average temperature } \\
{\left[{ }^{\circ} \mathrm{C}\right]}\end{array}$ \\
\hline $\begin{array}{l}\text { Antonimina Canolo } \\
\text { Nuovo }\end{array}$ & 880 & 1883.5 & 12.3 \\
\hline Bagnara Calabra & 30 & 1002.2 & n.a. \\
\hline Cittanova & 407 & 1465.8 & 16.2 \\
\hline $\begin{array}{l}\text { Gambarie } \\
\text { d'Aspromonte }\end{array}$ & 1300 & 1644.3 & 9.6 \\
\hline Gioia Tauro & 20 & 907.3 & n.a. \\
\hline Gioia Tauro Budello & 20 & 888.0 & n.a. \\
\hline Molochio & 310 & 1254.6 & n.a. \\
\hline Oppido & 342 & 1244.8 & n.a. \\
\hline Oppido Castellace & 189 & 1345.8 & n.a. \\
\hline Palmi & 248 & 1010.0 & 17.7 \\
\hline Perrone & 940 & 2211.0 & n.a. \\
\hline Platì & 310 & 1765.7 & 17.9 \\
\hline Rizziconi & 82 & 1109.2 & 16.9 \\
\hline Rizziconi Ponte Vecchio & 90 & 955.9 & n.a. \\
\hline San Luca Polsi & 786 & 2089.4 & 14.2 \\
\hline Santa Cristina & 510 & 1513.1 & 16.7 \\
\hline Scifà & 890 & 1607.2 & n.a. \\
\hline Sinopoli & 502 & 1391.3 & n.a. \\
\hline Taurianova & 210 & 1192.7 & n.a. \\
\hline & & & \\
\hline
\end{tabular}

Table 4: Average annual rainfall for each gauge and for each period. Legend: red $=$ rain less than the average of entire period; green = rain above the average of the entire period.

\begin{tabular}{|l|l|l|l|l|l|l|}
\hline Gauge & $\begin{array}{l}\text { Until 1954 } \\
{[\mathrm{mm}]}\end{array}$ & $\begin{array}{l}1955- \\
1988 \\
{[\mathrm{~mm}]}\end{array}$ & $\begin{array}{l}1989- \\
1997 \\
{[\mathrm{~mm}]}\end{array}$ & $\begin{array}{l}1998- \\
2004 \\
{[\mathrm{~mm}]}\end{array}$ & $\begin{array}{l}2005- \\
2006 \\
{[\mathrm{~mm}]}\end{array}$ & $\begin{array}{l}2007- \\
2011 \\
{[\mathrm{~mm}]}\end{array}$ \\
\hline Bagnara Calabra & 1022.6 & 954.2 & n.a. & n.a. & 865.6 & 1020.1 \\
\hline Cittanova & 1505.6 & 1530.5 & 1176.6 & 1195.4 & 1247.5 & 1326.9 \\
\hline $\begin{array}{l}\text { Gambarie } \\
\text { d'Aspromonte }\end{array}$ & 1898.3 & 1678.7 & 1217.1 & 1136.0 & n.a. & 1825.2 \\
\hline Palmi & 1023.4 & 967.8 & n.a. & 1052.2 & 1013.0 & 1003.3 \\
\hline Platì & 1841.1 & 1773.2 & 1619.6 & 1295.9 & 1712.6 & 1865.3 \\
\hline Rizziconi & 1099.3 & 1125.8 & 1176.0 & 1039.2 & 876.6 & 1090.5 \\
\hline Santa Cristina & 1704.9 & 1441.1 & 1410.9 & 1406.7 & n.a. & 1511.2 \\
\hline Sinopoli & 1431.4 & 1343.2 & 1242.4 & 1338.3 & 1379.7 & 1547.0 \\
\hline
\end{tabular}




\subsection{River sediment contribution}

River sediment contribution has been evaluated by the Gavrilovic model [35], which is based on an analytical equation to determine the annual volume of detached soil due to surface erosion. This equation depends on the average yearly precipitation, the average yearly temperature, the drainage area, the average slope of the basin and some coefficients related to the soil protection (function of type of vegetation cover), the erodibility (function of type of rock), the erosion and the stream network development (a function of the type of basin erosion). The value of average annual river sediment transport is about $125000 \mathrm{~m}^{3} /$ year.

\section{DISCUSSION AND CONCLUSIONS}

From the cross-analysis of the results shown in the paper it can be seen that the mouth of the Petrace River has alternated periods of advancement and erosion, often of considerable magnitude. In particular, in 1954 the beach had an amplitude of $265 \mathrm{~m}$ and between 1954 and 1985 it is possible to observe the greatest erosion, with retreat of about $200 \mathrm{~m}$. Over the next twenty years, minor movements have been observed, followed by a sudden erosion between 2005 and 2006 of about $40 \mathrm{~m}$, and an advancement between 2008 and 2011 of about $100 \mathrm{~m}$. Longshore and river transport is on the average of the same order of magnitude so that the evolutionary processes described above could be related to alterations, more or less timeconsuming, of the sedimentary regime. Thus, among the factors analyzed, there seems to be significant influence on the high amount of hydraulic structures that, as described above, are present in over $40 \%$ of the hydrographic grid and have resulted in an increase in the bottom by a total of $20 \%$ of main stream. Another factor that seems to have a significant impact on the study area is the rainfall since 1954, the year when the maximum width of the beach at the mouth of the Petrace River was observed, rainfall recorded by almost all gauges (except for Rizziconi gauge) are higher than the average value recorded over the entire period. Even in the period 2007-2011, where a remarkable advancement of the shoreline was observed, 4 of 8 gauges recorded higher values than the average of the whole period, 3 gauges recorder values slightly below this average and only the Cittanova gauge it has markedly lower values. It should also be noted that between 1951 and 1953 almost all of the province of Reggio Calabria was affected by two intense alluvial events that can explain the remarkable advancement observed at the mouth of the Petrace River.

\section{ACKNOWLEDGEMENT}

The authors thank Prof. Bombino of the Department of Agriculture of the Mediterranea University of Reggio Calabria for the useful information provided on the census of hydraulic structures in the Petrace River.

\section{REFERENCES}

[1] Burbridge, P.R., A critical review of progress towards Integrated Coastal Management in the Baltic sea region. Proceedings of BaltCoast2004 (Warnemunde, Germany), pp. 63-75, 2004.

[2] European Union, Sustainable tourism in the Mediterranean, 2012.

[3] Lanquar, R., Tourism in the Mediterranean: Scenarios up to 2030, MEDPRO report (1), 2011.

[4] Komar, P.D., Coastal erosion - underlying factors and human impacts. Shore \& Beach, 68(1), pp. 3-16, 2000. 
[5] Marin, V., Palmisani, F., Ivaldi, R., Dursi, R. \& Fabiano, M., Users' perception analysis for sustainable beach management in Italy. Ocean and Coastal Management, 52(5), pp. 268-277, 2009.

[6] Barbaro, G., A new expression for the direct calculation of the maximum wave force on vertical cylinders. Ocean Engineering, 34, pp. 1706-1710, 2007.

[7] Barbaro, G., Estimating design wave for offshore structures in Italian waters. Proceedings of the Institution of Civil Engineering, Maritime Engineering, 164, pp. 115-125, 2011.

[8] Barbaro G. \& Foti G., Shoreline behind a breakwater for wave energy absorption in Reggio Calabria: comparison between theoretical models and experimental data. Proceedings $2^{\text {nd }}$ International Conference on Physical Coastal Processes, Management and Engineering (Naples, Italy), pp. 237-248, 2011.

[9] Barbaro, G. \& Foti, G., Shoreline behind a breakwater: comparison between theoretical models and field measurements for the Reggio Calabria sea. Journal of Coastal Research, 29, pp. 216-224, 2013.

[10] Barbaro, G., Foti, G. \& Sicilia, C.L., Wave forces on upright breakwater, evaluation and case study. Disaster Advances, 6, pp. 90-95, 2013.

[11] Tomasicchio, G.R., D’Alessandro, F. \& Barbaro, G., Composite modelling for largescale experiments on wave-dune interaction. Journal of Hydraulic Research, 49, pp. 15-19, 2011.

[12] Phillips, M.R. \& Jones, A.L., Erosion and tourism infrastructure in the coastal zone: Problems, consequences and management. Tourism Management, 27(3), pp. 517-524, 2006.

[13] Maiti, S. \& Bhattacharya, A.K., Shoreline change analysis and its application to prediction: A remote sensing and statistics based approach. Marine Geology, 257(14), pp. 11-23, 2009.

[14] Komar, P.D., Beach Processes and Sedimentation, Prentice Hall: New Jersey, USA, 1998.

[15] Arena, F., Barbaro, G. \& Romolo, A., Return period of a sea storm with at least two waves higher than a fixed threshold. Mathematical Problems in Engineering, pp. 1-6, 2013.

[16] Arena, F., Laface, V., Barbaro, G. \& Romolo, A., Effects of sampling between data of significant wave height for intensity and duration of severe sea storms. International Journal of Geosciences, 4, pp. 240-248, 2013.

[17] Arena, F., Malara, G., Barbaro, G., Romolo, A. \& Ghiretti, S., Long-term modelling of wave run-up and overtopping during sea storms. Journal of Coastal Research, 29, pp. 419-429, 2013.

[18] Barbaro, G., Foti, G. \& Malara, G., Set-up due to random waves: influence of the directional spectrum. Proceedings $30^{\text {th }}$ International Conference on Ocean, Offshore and Artic Engineering (Rotterdam, The Netherlands), 2011.

[19] Barbaro, G., Foti, G. \& Malara, G., Set-up due to random waves: influence of the directional spectrum. International Journal of Maritime Engineering, 155, pp. A105A115, 2013.

[20] Boccotti, P., Wave mechanics and wave loads on marine structures, Elsevier BH: Oxford, UK, 2015.

[21] Boccotti, P., Arena, F., Fiamma, V., Romolo, A. \& Barbaro, G., Estimation of mean spectral directions in random seas. Ocean Engineering, 38, pp. 509-518, 2011. 
[22] Barbaro, G., Foti, G., Sicilia, C.L. \& Malara, G., A formula for the calculation of the longshore sediment transport including spectral effects. Journal of Coastal Research, 30, pp. 961-966, 2014.

[23] Lamberti, A. \& Tomasicchio, G.R., Stone mobility and longshore transport at reshaping breakwaters. Coastal Engineering, 29(3), pp. 263-289, 1997.

[24] Tomasicchio, G.R., Archetti, R., D'Alessandro, F. \& Sloth, P., Long-shore transport at berm breakwaters and gravel beaches. Proceedings of the International Conference Coastal Structures (Venice, Italy), pp. 65-76, 2007.

[25] Tomasicchio, G.R., D’Alessandro, F., Barbaro, G. \& Malara, G., General longshore transport model. Coastal Engineering, 71, pp. 28-36, 2013.

[26] Tomasicchio, G.R., D’Alessandro, F., Barbaro, G., Musci, E. \& De Giosa, T.M., Longshore transport at shingle beaches: an independent verification of the general model. Coastal Engineering, 104, pp. 69-75, 2015.

[27] Tomasicchio, G.R., Lamberti, A. \& Guiducci, F., Stone movement on a reshaped profile. Proceedings of the $24^{\text {th }}$ International Conference on Coastal Engineering (Kobe, Japan), pp. 1625-1640, 1994.

[28] Sicilia, C.L., Foti, G. \& Campolo, A., Protection and management of the Annunziata river mouth area (Italy). Journal of Air, Soil and Water Research, 6, pp. 107-113, 2013.

[29] Barbaro, G., Foti, G. \& Sicilia, C.L., Coastal erosion in the South of Italy. Disaster Advances, 7, pp. 37-42, 2014.

[30] Barbaro G., Foti G. \& Sicilia C.L., Historical Evolution of the Shoreline of Reggio Calabria. Advanced Engineering Forum, 11, pp. 157-162, 2014.

[31] Barbaro, G., Saline Joniche: a predicted disaster. Disaster Advances, 6, pp. 1-3, 2013.

[32] Barbaro, G., Master Plan of solutions to mitigate the risk of coastal erosion in Calabria (Italy), a case study. Ocean \& Coastal Management, 132, pp. 24-35, 2016.

[33] Foti G. \& Sicilia C.L., Analysis, evaluation and innovative methodologies to prevent coastal erosion. Proceedings $3^{\text {rd }}$ International Conference on Physical Coastal Processes, Management and Engineering, Gran Canaria (Spain), 2013.

[34] Ewing, J.A., An assessment of two wave prediction models: Hindwave and Bristwave, Wallingford HR, 1989.

[35] Gavrilovic, S., Méthode de la classification des bassins torrentiels et équations nouvelles pour le calcul des hautes eaux et du débit solide. Vadoprivreda, Belgrado, Serbia, 1959 (in French). 